\title{
Importance of evaluating the presence of temporomandibular disorders in chronic pain patients*
}

\author{
A importância da avaliação da presença de disfunção temporomandibular em pacientes com \\ dor crônica
}

Luci Mara França Correia1, Wagner Hummig', Taísa Adamowicz¹, Daniel Benzecry de Almeida

${ }^{*}$ Received from the Institute of Neurology of, Curitiba, PR, Brazil.

DOI 10.5935/1806-0013.20140002

\section{ABSTRACT}

BACKGROUND AND OBJECTIVES: Chronic pain patients have lower pain threshold, thus having pain in other parts of the body. This study aimed at evaluating the presence of temporomandibular disorders in patients with chronic pain in different parts of the body comparing them to a pain-free control group. In addition, we tried to determine which group had more temporomandibular disorder symptoms and myofascial changes in masticatory muscles. METHODS: Sample was made up of 180 individuals divided in 2 groups, being 90 patients with chronic pain in different parts of the body: study group, and 90 pain-free patients: control group. The questionnaire proposed by the American Academy of Orofacial Pain was used to diagnose temporomandibular disorder symptoms. A directed and validated physical evaluation was performed. Analyses were done to determine the frequency of temporomandibular symptoms both in the control group and the study group, and the presence of muscular temporomandibular disorders in both groups.

RESULTS: Among chronic pain patients, 70\% had temporomandibular disorder symptoms and in the control group they were $55 \%$. Patients with symptoms were physically evaluated and it was observed that $45 \%$ had masticatory muscles myofascial pain as compared to $28 \%$ in the control group.

CONCLUSION: The prevalence of temporomandibular disorder symptoms and masticatory muscles pain was higher among chronic pain patients as compared to the control group and should be taken into consideration when the proposal is to evaluate and control all pains of such patients.

Keywords: Chronic pain, Facial pain, Temporomandibular joint disorder syndrome.

1. Institute of Neurology of Curitiba, Curitiba, PR, Brazil.

Submitted in September 03, 2013.

Accepted for publication in January 29, 2014.

Conflict of interests: none.

Correspondence to:

Luci Mara França Correia

Rua Paraíba 2902 - Bairro Guaíra

80630-000 Curitiba, PR, Brasil.

E-mail: draluci.dor@gmail.com

(C) Sociedade Brasileira para o Estudo da Dor

\section{RESUMO}

JUSTIFICATIVA E OBJETIVOS: Pacientes com dor crônica apresentam um menor limiar à dor apresentando dessa forma dores em outras topografias. O objetivo deste estudo foi avaliar a presença de disfunção temporomandibular em pacientes com dor crônica em diversas partes do corpo comparando com um grupo controle sem sintomatologia dolorosa. Além disso, buscou-se verificar qual dos grupos apresentou mais sintomas de disfunção temporomandibular e alteração miofascial nos músculos da mastigação.

MÉTODOS: A amostra foi composta por 180 indivíduos, divididos em 2 grupos, sendo 90 pacientes com dor crônica em diversas partes do corpo: grupo estudo, e 90 pacientes sem sintomatologia dolorosa: grupo controle. Para o diagnóstico da sintomatologia de disfunção temporomandibular foi utilizado o questionário proposto pela Academia Americana de Dor Orofacial. Foi realizada uma avaliação física dirigida e validada. Análises foram feitas para verificar a frequência de sintoma de disfunção temporomandibular tanto no grupo controle quanto no grupo estudo e a presença de disfunção temporomandibular muscular em ambos os grupos.

RESULTADOS: Entre os pacientes com dor crônica $70 \%$ apresentaram sintomatologia para disfunção temporomandibular e no grupo controle $55 \%$. Os pacientes que apresentaram sintomatologia foram avaliados fisicamente e constatou-se que $45 \%$ apresentaram dor miofascial nos músculos da mastigação, contra 28\% no grupo controle.

CONCLUSÃO: A presença de sintomatologia de disfunção temporomandibular e dor muscular nos músculos da mastigação foi maior em pacientes com dor crônica em relação ao grupo controle e deve ser levada em consideraçáo quando se propóe avaliar e controlar todas as dores nesses pacientes.

Descritores: Dor crônica, Dor facial, Síndrome da disfunção da articulação temporomandibular.

\section{INTRODUCTION}

Temporomandibular disorders (TMD) are a subgroup of orofacial pains characterized by a set of craniofacial changes of multifactorial etiology, with symptoms including movement limitation and pain in pre-auricular region, temporomandibular joint (TMJ), masticatory muscles and head and neck 
musculoskeletal structures. Pain of any nature induces neurovegetative nervous system hyperactivity and increased muscle tone with consequent onset of myofascial pain ${ }^{1}$.

Pain may be sudden or progress with different frequencies and intensities for months or years, with characteristics of chronic disease. Click, crackle, locking, mouth opening limitation or mandible movement shift and headache are also associated to $\mathrm{TMD}^{1}$.

Clinical trials have shown that orofacial pain patients often have pain in other body regions in addition to the masticatory system, such as arms, hands, cervical, dorsal and lumbar regions and lower limbs ${ }^{2-4}$. In addition, some studies have suggested that pain in other body regions may be a risk factor to the development of TMDs ${ }^{5,6}$ and may also contribute to masticatory muscles myofascial pain persistence ${ }^{7,8}$, making even more difficult to control pain in these patients with chronic presentation.

Based on presented data, this study aimed at evaluating the frequency of muscular TMD in patients with chronic pain (CP) in other body regions who looked for multidisciplinary assistance with pain not primarily related to TMJ.

\section{METHODS}

This was a transversal observational study carried out from August 2011 to May 2012, where 90 CP patients were evaluated by two dentists from the pain group of the ambulatory of the Institute of Neurology of Curitiba, PR (INC).

The study group (SG) was made up of 90 patients, above 18 years of age, with chronic nociceptive myofascial pain, based on the presence of myofascial trigger-points at palpation for at least six months in different body regions and being followed up by the INC pain group. At the same time, these patients could not have any type of neuralgia.

The control group (CG) was made up of individuals above 18 years of age, belonging to the INC staff, escorts or relatives of patients without history of acute or chronic pain.

Both groups were paired by gender and age. Groups were made up of 90 individuals, being 65 females and 25 males, mean age of 47 years. To evaluate the possible presence of TMD, all 180 individuals have filled out an orofacial pain and TMD screening questionnaire recommended by the American Academy of Orofacial Pain (AAOP), which is composed of 10 questions with closed answers (yes or no), addressing most frequent signs and symptoms of these diseases.

When there was a positive answer, the individual was referred to physical evaluation based on validated diagnostic criteria: the Research Diagnostic Criteria for Temporomandibular Disorders (RDC/TMD). This physical evaluation was performed by two previously trained dentists and involved palpation of masseter and temporal muscles to the right and to the left, with pressure equivalent to $1 \mathrm{kgf}$.

Pearson Chi-square test was used to compare frequencies of TMD symptoms and muscle TMD diagnoses between groups. Chi-square test was also applied to check differ- ences in frequency of pain sites in CG volunteers among those being or not diagnosed with TMD. Significance level was 0.05 .

This study was approved by the Research Ethics Committee, Institute of Neurology of Curitiba, PR, under n. 074/2011.

\section{RESULTS}

During TMD symptoms evaluation, 50 CG individuals have positively answered to at least one symptom of the questionnaire, and 63 SG individuals have presented at least one symptom. By applying Chi-square test, it was possible to observe that SG had more TMD symptoms as compared to CG $(\mathrm{p}=0.045)$ (Table 1)

Table 1. Temporomandibular disorder symtoms

\begin{tabular}{lcc}
\hline & With TMD symptoms & Without TMD symptoms \\
\hline Study group & 63 & 27 \\
Control group & 50 & 40 \\
\hline
\end{tabular}

Chi-square test $\mathrm{p}=0.045$.

With regard to muscle TMD, SG has also presented the highest number of individuals with significant association $(\mathrm{p}=0.02)$ (Table 2).

Table 2. Diagnosis of muscle temporomandibular disorder

\begin{tabular}{lcc}
\hline & With muscle TMD & Without muscle TMD \\
\hline Study group & 40 & 50 \\
Control group & 25 & 65 \\
\hline
\end{tabular}

Chi-square test $\mathrm{p}=0.02$.

From 90 SG group patients being treated for CP, 13 had myofascial pain in cervical region, 14 had myofascial pain in the upper region of the body, that is, in addition to cervical pain there was also the involvement of upper limbs, 19 had myofascial pain in lower limbs, 20 had myofascial pain in lumbar region, 14 with widespread pain and 10 with headaches. According to descriptive data analysis in table 1, the presence of face myofascial pain, characterizing muscle TMD, evaluated in these patients, has shown that TMD ratio in this study was higher in cases of widespread pain, as described in table 3 .

Table 3. Frequency of painful sites in the study group $n(\%)$

\begin{tabular}{lccc}
\hline Painful region & $\begin{array}{c}\text { People with } \\
\text { TMD } \\
(\mathrm{n}=40)\end{array}$ & $\begin{array}{c}\text { People } \\
\text { without TMD } \\
(\mathrm{n}=50)\end{array}$ & p value \\
\hline Cervical & $7(7.78)$ & $6(6.67)$ & $0.46^{*}$ \\
Upper limbs & $7(7.78)$ & $7(7.78)$ & $0.65^{\star}$ \\
Lower limbs & $7(7.78)$ & $12(13.33)$ & $0.45^{*}$ \\
Lumbar & $4(4.44)$ & $16(17.78)$ & $0.011^{* *}$ \\
Widespread pain & $10(11.11)$ & $4(4.44)$ & $0.027^{* *}$ \\
Headache & $5(5.56)$ & $5(5.56)$ & $0.71^{*}$ \\
\hline${ }^{*}$ Chi-square test ${ }^{* *}$ Fisher Exact test. & &
\end{tabular}




\section{DISCUSSION}

Our study has shown that patients with CP in other body regions are more likely to have orofacial symptoms and masticatory muscles myofascial pain as compared to control group. A study ${ }^{9}$ has reported such relationship and has found symptoms sharing in different body regions when evaluating $\mathrm{CP}$ patients. The opposite also seems to be true. A different study ${ }^{3}$ has found that $76 \%$ of TMD patients also reported pain in other body regions; $50 \%$ of adult patients with orofacial pain had also widespread pain ${ }^{10}$.

A major challenge for health professionals is to manage these patients because pain in one site may be influencing the other and vice versa, impairing the control of the symptom. Individuals with myofascial pain and history of widespread pain seem to have more frequent persistent pain, as compared to patients with no history of widespread pain ${ }^{7}$. These data strengthen the need to understand painful areas of each patient.

Curiously, in a fibromyalgia study ${ }^{11}$, investigators have found that facial pain, headaches, fatigue and mandible movement functional limitation were prevalent among fibromyalgia patients, and suggest that fibromyalgia starts in other body regions and then extends to the orofacial region. According to this study, the highest prevalence of muscle TMD was found among patients with widespread pain, confirming the fact that pains add up, thus the need for recognizing them so that they may be controlled. In remaining pain sites, SG presented, in a virtually balanced way, the presence or not of TMD, with significant result of the relationship in the group with pain in different body regions, which is different from the vast majority of studies found in the literature. Many studies show cervical pain closely related to TMD ${ }^{12,13}$. This brings the need for a study with a larger number of individuals in each group to increase the potential of comparison of painful body areas and the presence of simultaneous muscle TMD.

Understanding CP and how it behaves for each individual is still reason for many studies and observations, as well as the fact that TMD etiology is still not totally explained. It is necessary to know this inter-relation to control pain of patients with these disorders.

Our results show the importance of thorough evaluation of $\mathrm{CP}$ individuals, because patients with pain in other body re- gions have more masticatory muscles myofascial pain as compared to control group. This is important for the management of such patients, confirming the real need for a multiprofessional approach to reach complete and global physical recovery of such individuals.

\section{CONCLUSION}

The frequency of TMD symptoms and masticatory muscles myofascial pain in patients being treated for chronic muscle pain in other body regions was higher than in the group with no pain and should be taken into consideration during general physical evaluation of these patients.

\section{REFERENCES}

1. Teixeira MJ. Fisiopatologia da nocicepção e supressão da dor. JBA 2001;1(4):329-34.

2. Hagberg C. General musculoskeletal complaints in a group of patients with craniomandibular disorders (CMD). A case control study. Swed Dent J. 1991;15(4):179-85.

3. Türp JC, Kowalski CJ, O'Leary N, Stohler CS. Pain maps from facial pain patients indicate a broad pain geography. J Dent Res. 1998;77(6):1465-72.

4. McMillan AS, Wong MC, Zheng J, Luo Y, Lam CLK. Widespread pain symptoms and psychological distress in southern Chinese with orofacial pain. J Oral Rehabil. 2010;37(1):2-10.

5. John MT, Miglioretti DL, LeResche L, Korff MV, Critchlow CW. Widespread pain as a risk factor for dysfunctional temporomandibular disorder pain. Pain. 2003;102(3):257-63

6. Velly AM, Look JO, Schiffman E, Lenton PA, Kang W, Messner RP, et al. The effect of fibromyalgia and widespread pain on the clinically significant temporomandibular muscle and joint pain disorders a prospective 18-month cohort study. J Pain. 2010;11(11):1155-64.

7. Raphael KG, Marbach JJ, Klausner J. Myofascial face pain. Clinical characteristics of those with regional vs. widespread pain. J Am Dent Assoc. 2000;131(2):161-71.

8. Macfarlane TV, Blinkhorn AS, Davies RM, Kincey J. Worthington HV. Predictors of outcome for orofacial pain in the general population: a four-year follow-up study. J Dent Res. 2004;83(9):712-7

9. Aaron LA, Burke MM, Buchwald D. Overlapping conditions among patients with chronic fatigue syndrome, fibromyalgia, and temporomandibular disorder. Arch Intern Med 2000;160:221-7.

10. Sipilä K, Ylöstalo PV, Joukamaa M, Knuuttlila ML. Comorbidity between facia pain, widespread pain, and depressive symptoms in young adults. J Orofac Pain. 2006;20(1):24-30.

11. Hedenberg-Magnusson B, Ernberg M, Kopp S. Presence of orofacial pain and temporomandibular disorder in fibromyalgia. A study by questionnaire.Swed Dent J 1999;23:185-92.

12. Olivo SA, Fuentes J, Major PW, Warren S, Thie NM. The association between neck disability and jaw disability. J Oral Rehabil. 2010;37(9):670-9.

13. Wiesinger B, Malker H, Englund E, Wanman A. Does a dose-response relation exis between spinal pain and temporomandibular disorders? BMC Musculoskelet Disord. 2009;2;10:28 